\title{
Detection of Novel Gammaherpesviruses in Wild Animals of South Africa
}

\author{
Ochir PAGAMJAV ${ }^{1)}$, Tohru SAKATA ${ }^{2)}$, El-Sayed M. IBRAHIM ${ }^{1)}$, Chihiro SUGIMOTO ${ }^{3)}$, Shinji TAKAI ${ }^{4)}$, Janusz T. \\ PAWESKA $^{5)}$, Tsuyoshi YAMAGUCHI ${ }^{1,2)}$, Jun YASUDA ${ }^{6)}$ and Hideto FUKUSHI ${ }^{1,2) *}$
}

\begin{abstract}
${ }^{1)}$ Department of Applied Veterinary Sciences, United Graduate School of Veterinary Sciences, and ${ }^{2)}$ Laboratory of Veterinary Microbiology, Faculty of Applied Biological Sciences, Gifu University, 1-1 Yanagido, Gifu 501-1193, ${ }^{3)}$ National Research Center for Protozoan Diseases, Obihiro University of Agriculture and Veterinary Medicine, Inada-cho, Obihiro, Hokkaido 080-8555, ${ }^{4)}$ Department of Animal Hygiene, School of Veterinary Medicine and Animal Sciences, Kitasato University, Towada, Aomori 034-8628, Japan, ${ }^{5}$ Special Pathogens Unit, National Institute for Communicable Diseases, Private Bag X4, Sandringham 2131, Republic of South Africa and 6) Veterinary Teaching Hospital, Faculty of Agriculture, Iwate University, 3-18-8 Ueda, Morioka, 020-8550, Japan
\end{abstract}

(Received 12 November 2004/Accepted 15 July 2005)

ABSTRACT. Herpesviral DNA was detected in 24/261 DNA samples that were extracted from whole blood of 13 wild animal species in South Africa. Herpesviral DNA was shown in 22 impalas (Aepyceros melampus) and 2 springboks (Antidorcas marsupialis). All of DNA sequences detected in impalas were identical, whereas two DNA sequences detected in springboks were different each other. These three sequences showed 44 to $72 \%$ homology to the corresponding gene of the Gammaherpesvirinae, indicating that these three viruses should be unrecognized novel gammaherpesviruses. The putative novel herpesviruses were tentatively designated as Aepyceros melampus (impala) herpesvirus 1 (ImHV-1), Antidorcas marsupialis (springbok) herpesviruses 1 (SpHV-1) and 2 (SpHV-2). ImHV-1 seems to be a relatively independent virus. SpHV-1 belongs to a group of ruminant lymphotropic herpesviruses and SpHV-2 is closer to a malignant catarrhal fever virus group. Potential threat of these herpesviruses to domestic animals should be considered. KEY WORDS: Gammaherpesvirus, impala, springbok.

Much attention is paid to the role of wild animals in the transmission of diseases to livestock. Converse situation have also been reported where livestock serve as a source of infection for wild animals [24]. Although, outbreaks or natural disease in wild animals are limited. Neutralizing antibodies to a number of common viral pathogens of domestic animals have been found in sera of wild animals [2, 4, 7], including antibodies against Allerton disease, equid herpes virus-1, bovid herpesvirus-2, and infectious bovine rhinotracheitis. It appears that herpesviruses be more common in wild animals than other viruses. Herpesviruses comprise a large group of viruses causing widespread diseases in man, domestic and wild animals [20]. A feature of all herpesvirus infections is lifelong persistence of the virus in the body, usually in latent form. Sites of latent infection include trigeminal ganglions $[1,19]$ and lymphocytes $[6,11]$. Virus in persistently infected tissue can be diagnosed by PCR and other molecular methods [8].

The herpesvirus DNA polymerase gene has been widely used as a target for the detection of new herpesviruses and investigation of their evolutionary relationships $[3,4,12$, $18,21,22]$. DNA polymerase gene sequence alignments correlate highly with the subfamily classification of herpesviruses, which is based on a variety of biological properties $[15,20,23]$.

In this study, we attempted to detect herpesviruses in wild animals of South Africa, which has exported wild animals to other countries for display, research and so on. We found

\footnotetext{
* Correspondence to: Fukushi, H., Laboratory of Veterinary Microbiology, Faculty of Applied Biological Sciences, Gifu University, 1-1 Yanagido, Gifu 501-1193, Japan.
}

three herpesvirus-related DNA polymerase gene sequences in impalas and springboks, indicating that there were three unrecognized novel members of gammaherpesvirus.

Whole blood was taken from 261 animals of 13 species in South Africa from 2000 to 2001 for routine tests during quarantine before export (Table 1). Total DNA of peripheral leucocytes was extracted with a Sepagene kit (Sanko Junyaku, Japan). Amplification of herpesvirus DNA was performed with the nested PCR using degenerated consensus primers targeting to the highly conserved region of the herpesvirus DNA polymerase gene $[5,12]$. Amplification conditions for the consensus PCR was described by Li et al. [12]. All amplified fragments were purified from electro-

Table 1. Detection of gammaherpesvirus DNA polymerase gene in blood samples collected in wild animals in South Africa

\begin{tabular}{|c|c|c|c|}
\hline \multicolumn{2}{|c|}{ Animal species } & \multirow{2}{*}{$\begin{array}{l}\text { No. positive } \\
\text { /no. tested }\end{array}$} & \multirow{2}{*}{$\begin{array}{c}\% \\
\text { positive }\end{array}$} \\
\hline Common name & Scientific name & & \\
\hline Springbok & Antidorcas marsupialis & $2 / 84$ & 2.4 \\
\hline Impala & Aepyceros melampus & $22 / 49$ & 44.9 \\
\hline Cape buffalo & Syncerus caffer & $0 / 34$ & 0 \\
\hline Kudu & Tragelaphus strepsiceros & $0 / 32$ & 0 \\
\hline Giraffe & Geraffa camelopardalis & $0 / 21$ & 0 \\
\hline Eland & Tragelaphus oryx & $0 / 13$ & 0 \\
\hline Blue wildebeest & Connochaetes taurinus & $0 / 9$ & 0 \\
\hline Black wildebeest & Connochaetes gnou & $0 / 8$ & 0 \\
\hline Rhinoceros & Ceratotherium simu & $0 / 5$ & 0 \\
\hline Zebra & Equus zebra & $0 / 3$ & 0 \\
\hline Hyena & Crocuta crocuta & $0 / 1$ & 0 \\
\hline Lion & Panthera leo & $0 / 1$ & 0 \\
\hline Blesbok & Damaliscus albifrons & $0 / 1$ & 0 \\
\hline Total & & $24 / 261$ & 9.2 \\
\hline
\end{tabular}




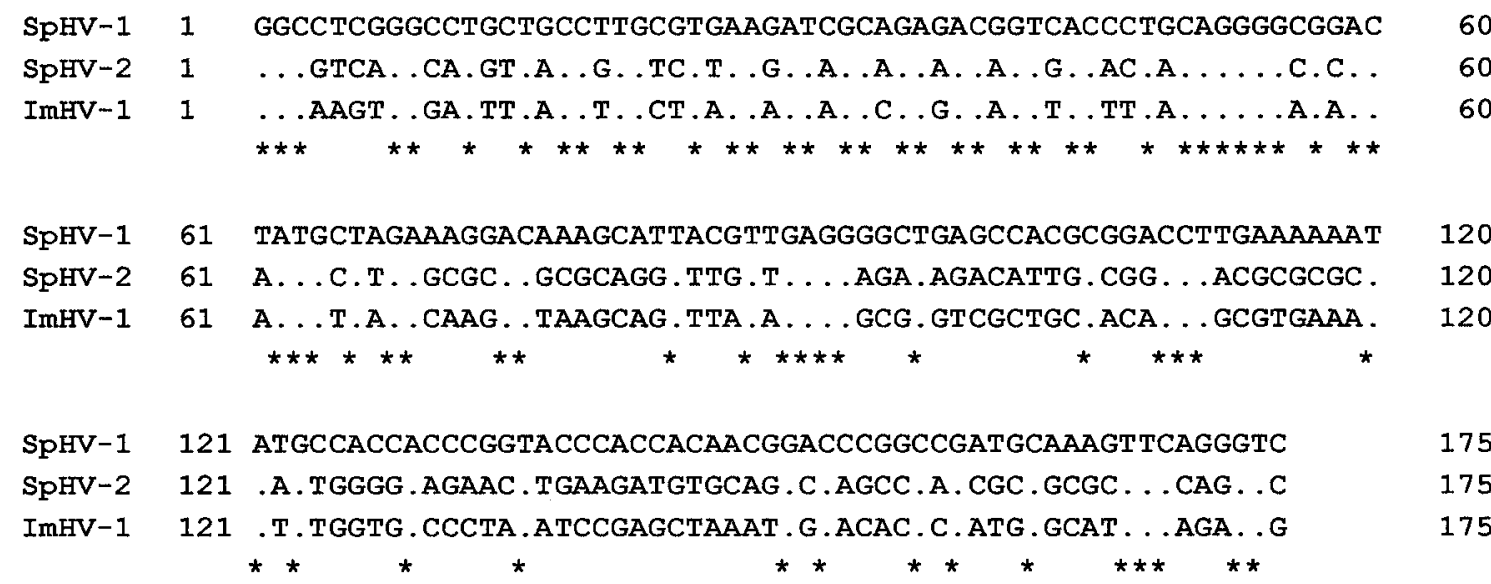

Fig.1. Comparison of the nucleotide sequences of a region of the herpesviral DNA polymerase gene detected from springbok and impala. Asterisks indicate nucleotides that are identical among the three strains. SpHV-1: Springbok herpesvirus-1 (Accession number AB194010); SpHV-2: Springbok herpesvirus-2 (Accesion number AB194011); ImHV-1: Impala herpesvirus-1 (Accession number AB194012).

phoresis gels using a QIAQuick Gel Extraction Kit (QIAGEN, Inc., U.S.A.). PCR products were ligated into pGEM-T easy vector (Promega, U.S.A.) with a TaKaRa Ligation Kit (TaKaRa, Japan) to transform competent Esherichia coli DH5 $\alpha$ cells (Life Technologies, Japan). At least three clones from each PCR product were selected for sequencing. Recombinant plasmid DNA was extracted with a Flexi Prep Kit (Amersham-Pharmacia, Japan). DNA fragments were sequenced with a ThermoSequenase Cycle Sequencing kit (Amersham-Pharmacia, Japan) and M13 universal and reversal Cy5.5-labeled primers by GeneRapid system (Amersham-Pharmacia, Japan) in house and some fragment were read at DragonGenomic Inc., Mie, Japan. Sequences were assembled and analyzed with GenetyxMAC/ATSQ and GENETYX-Mac (SDC, Japan).

Homology analysis was examined using the DDBJ Homology Search System (http://www.ddbj.nig.ac.jp/Email/homology.html) and NCBI-Blast (http://www.ncbi. nlm.nih.gov/BLAST). Sequences were multiple aligned by CLUSTAL X program [9]. Phylogenetic trees were constructed on predicted amino acid sequence alignments using the PROTDIST, NEIGHBOR and DRAWTREE of PHYLIP program package (University of Washington, U.S.A.). The phylogenetic tree was statistically evaluated using bootstrap analysis (100-fold resampling) by programs Seqboot and ConsensUS in the PHYLIP package.

Twenty-four (9.2\%) out of 261 blood samples collected from 13 wild animal species in South Africa were PCR-positive (Table 1). PCR products were detected in two species of impalas and springboks with the positive rates of 22/49 $(44.9 \%)$ and $2 / 84(2.4 \%)$, respectively.

Three kinds of DNA sequences were found in the 24 PCR-positive samples (Fig. 1). All the 22 sequences of impala samples were identical. Two sequences in springbok were different from each other as well as from the impala sequences. Comparing the predicted amino acid sequences of these three sequences by database search using BLAST, we could not find any sequences higher than $72 \%$ identity. The database search indicated that these three viruses should be unrecognized novel gammaherpesviruses. These putative novel herpesviruses were tentatively designated as Aepyceros melampus (impala) herpesvirus 1 (ImHV-1), Antidorcas marsupialis (springbok) herpesviruses 1 (SpHV1) and 2 (SpHV-2). DNA sequences reported in this paper were deposited in DDBJ under accession numbers of AB194012 for ImHV-1, AB194010 for SpHV-1, and AB194011 for SpHV-2. The closer sequences were caprine herpesvirus 2 (62\% identity) and alcelaphine herpesvirus 1 (60\% identiy) for ImHV-1, American bison gammaherpesvirus, bison herpesvirus and caprine lymphotropic herpesvirus (71\% identities) for SpHV-1, and caprine herpesvirus 2 (62\% identity) and alcelaphine herpesvirus 1 (60\% identiy) for SpHV-2 (Fig. 2).

Phylogeny analysis indicated that ImpHV seems to be independent on other members of gammaherpesviruses, whereas SpHV-1 would be a member of non-malignant catarrhal fever (MCF) group including lymphotropic herpesviruses of wild and domestic ruminants. SpHV-2 would be relatively closer to malignant catarrhal fever viruses (Fig. $3)$.

We detected three potentially new herpesviruses in impala and springbok, although we could not perform virus isolation. The results indicated that one of springbok was infected with a herpesvirus, SpHV-1, which should be a non-MCF group virus including so-called 'ruminant lymphotropic herpesvirus' group and rhadinoviruses (Fig. 3). SpHV-2 seemed to be relatively closer to a malignant catarrhal fever virus group. ImHV-1 does not belong to any known group of gammaherpesvirus. Gammaherpesviruses are known to be lymphotropic. Other investigators identified an unknown herpesvirus in cattle (bovine lymhotropic herpesvirus) and five known ovine herpesviruses [21] and 


\begin{tabular}{|c|c|}
\hline $\begin{array}{l}\text { Viruses } \\
\text { Springbok HV1 }\end{array}$ & $\begin{array}{l}\text { Acc. No. } \\
\text { AB194010 }\end{array}$ \\
\hline American Bison HV & $\overline{\text { AAI29891 }}$ \\
\hline Bison HV & AA088179 \\
\hline Caprine Lymphotropic HV & AAG10783 \\
\hline Bovine Iymphotropic HV & AAK28843 \\
\hline Bovine Lymphotropic HV & AAO 88182 \\
\hline Bighorn sheep HV & AAO88175 \\
\hline Sheep HV & AA088176 \\
\hline Addax HV & AA088181 \\
\hline Oryx HV & AA061285 \\
\hline Pygmy hippopotamus HV & AAP4 2117 \\
\hline Porcine Lymphotropic HV1 & AAE1 6520 \\
\hline Porcine Lymphotropic HV2 & AAO1 2282 \\
\hline Porcine Lymphotropic HV3 & AAO12315 \\
\hline Sus barbatus HV & AAO4 6909 \\
\hline Black-tailed deer HV & AA088177 \\
\hline Mule deer HV & AA088178 \\
\hline Elk HV & AA088180 \\
\hline Caprine HV2 & AAG13396 \\
\hline$=\mathrm{HV} 2$ & AAK28844 \\
\hline DX MCFV & AA061282 \\
\hline Alcelaphine HV1 & NP_065512 \\
\hline Alcelaphine HV2 & AAM1 9757 \\
\hline Springbok HV2 & AB194011 \\
\hline TapirHV & $\overline{\mathrm{AAD} 30142}$ \\
\hline Impala HV1 & AB194012 \\
\hline Saimiriine HV2 & CAC84304 \\
\hline Ateline HV3 & AAC 95533 \\
\hline Black Rhinoceros HV & AAK00812 \\
\hline Diceros bicornis HV & AAP42118 \\
\hline BHV-4 & AAC59454 \\
\hline Babyrouse HV & $\mathrm{AAO} 46970$ \\
\hline EBV (HHV4) & CAD53462 \\
\hline HHV-8 & AAC57086 \\
\hline Gibbon HV & AAs17748 \\
\hline Macaca nemestrina HV & AAF81662 \\
\hline Gorilla HV & AAG2 3218 \\
\hline Whale HV & AAV686930 \\
\hline Badger HV & AAL5 5728 \\
\hline EHV-2 & NP_042605 \\
\hline
\end{tabular}

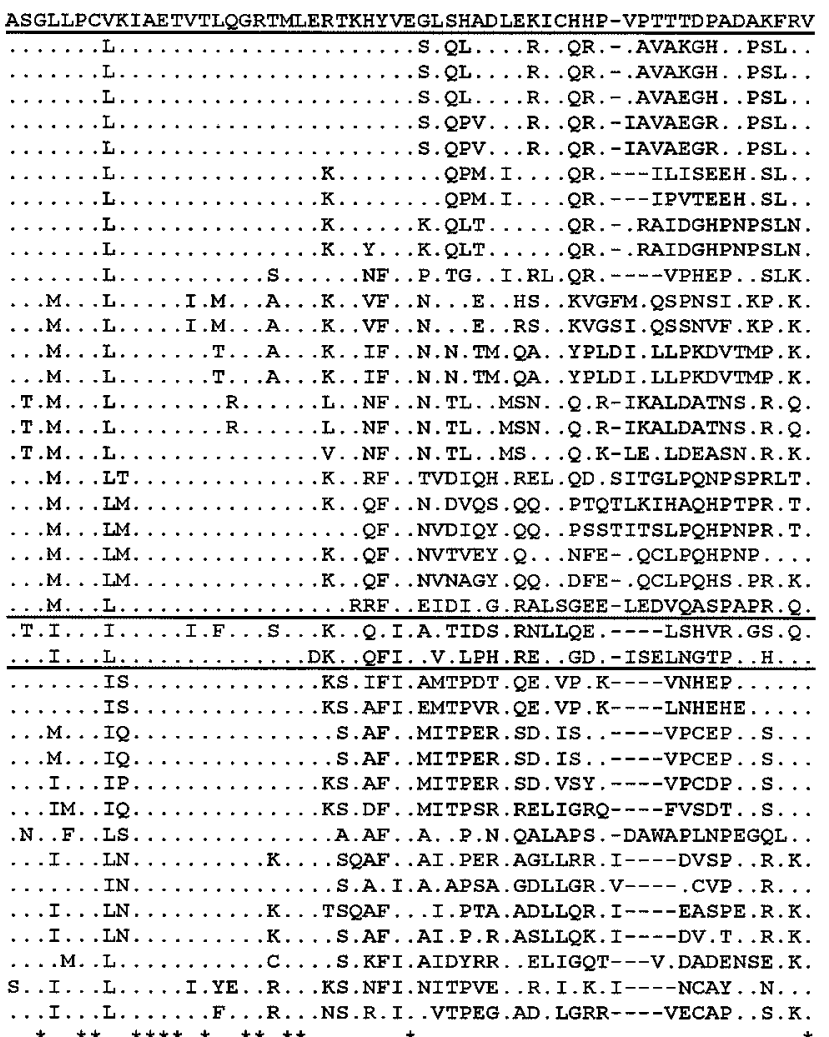

\begin{tabular}{|c|c|c|}
\hline SpHV-1 & SpHV-2 & ImHV-1 \\
\hline 100 & 49 & 58 \\
\hline$\overline{71}$ & $\overline{51}$ & $\overline{56}$ \\
\hline 71 & 51 & 56 \\
\hline 71 & 51 & 56 \\
\hline 68 & 49 & 56 \\
\hline 68 & 49 & 56 \\
\hline 66 & 44 & 56 \\
\hline 66 & 44 & 54 \\
\hline 64 & 49 & 56 \\
\hline 63 & 49 & 56 \\
\hline 59 & 53 & 51 \\
\hline 56 & 47 & 51 \\
\hline 56 & 47 & 54 \\
\hline 53 & 49 & 53 \\
\hline 53 & 49 & 53 \\
\hline 54 & 53 & 54 \\
\hline 54 & 53 & 54 \\
\hline 59 & 54 & 53 \\
\hline 47 & 61 & 62 \\
\hline 51 & 58 & 54 \\
\hline 51 & 59 & 58 \\
\hline 54 & 55 & 60 \\
\hline 53 & 54 & 58 \\
\hline 51 & 100 & 51 \\
\hline$\overline{46}$ & $\overline{46}$ & $\overline{51}$ \\
\hline 58 & $\underline{51}$ & 100 \\
\hline 54 & $\overline{44}$ & $\overline{58}$ \\
\hline 53 & 44 & 56 \\
\hline 56 & 53 & 53 \\
\hline 56 & 53 & 53 \\
\hline 53 & 49 & 56 \\
\hline 47 & 49 & 54 \\
\hline 51 & 49 & 46 \\
\hline 49 & 54 & 51 \\
\hline 58 & 49 & 53 \\
\hline 47 & 54 & 51 \\
\hline 53 & 53 & 51 \\
\hline 47 & 53 & 47 \\
\hline 47 & 53 & 53 \\
\hline 47 & 49 & 56 \\
\hline
\end{tabular}

Fig. 2. Comparison of the predicted amino acid sequences of the herpesviral DNA polymerase gene detected in springbok (SpHV-1, SpHV2), impala (ImHV-1), and other viruses. All these sequences were obtained from the National Center for Biotechnology Information database. Dots indicated that the corresponding amino acids are the same as those of SpHV-1 sequence. Asterisks in the bottom line indicate amino acid that are identical in all the viruses. Hyphens indicate the lack of corresponding amino acids. Data on ImHV-1, SpHV-1, and SpHV-2 are indicated by underline. Numbers under SpHV-1, SpHV-2 and ImHV-1 are identity percentages. Virus names with accession numbers are indicated.

new herpesviruses from wild animals including muskox (Ovibos moschatus), Nubian ibex (Capra nubian) and Southern African oryx (Oryx gazella) [13] with these same primers used here. Many gammaherpesviruses may be prevalent and some can infect not only their natural hosts but also other ruminants as accessory hosts [3, 10, 12, 14, 17, 21, 22]. All samples examined at the present study were taken from apparently healthy animals. Our results suggest that there may be a large number of gammaherpesviruses infecting ruminants without clinical symptoms in the natural hosts.

It is not known whether the three new gammaherpesviruses found in this study are pathogenic in other animals including domestic animals and human beings. However, MCF virus has been reported to infect other animals and cause severe epizootics with high morbidity and mortality $[10,12]$. Therefore, further investigations are needed to study the pathogenicity of the new viruses in wild and domestic animals.

ACKNOWLEDGEMENT. This study was supported by
Grants-in-Aid for Basic Scientific Research (No. 11691164 , 15255021 and No. 17255010) and the 21st Century Centerof-Excellence Program (E-1) from the Ministry of Education, Culture, Sports, Science and Technology, Government of Japan.

\section{REFERENCES}

1. Baringer, J.R. and Swoveland, P. 1973. New Engl. J. Med. 288: 648-650.

2. Barnard, B.J. 1997. Onderstepoort J. Vet. Res. 64: 95-110.

3. Chmielewicz, B., Goltz, M. and Ehlers, B. 2001. Virus Res. 75 : 87-94.

4. Eberle, R. 1992. J. Med. Primatol. 21: 246-251.

5. Ehlers, B., Borchers, K., Grund, C., Frolich, K., Ludwig, H. and Buhk, H. J. 1999. Virus Genes 18: 211-220.

6. Graze, P.R. and Royston, I. 1975. Arch. Virol. 49: 165-174.

7. Hamblin, C. and Hedger, R.S. 1982. J. Wildl.Dis. 18: 429-436.

8. Ito, J. and Braithwaite, D.K. 1991. Nucleic. Acids. Res. 19: 4045-4057.

9. Jeanmougin, F., Thompson, J. D., Gouy, M., Higgins, D.G. and Gibson, T. J. 1998. Trends. Biochem. Sci. 23: 403-405.

10. Keel. M. K., Patterson, J. G., Noon, T. H., Bradley, G. A. and 


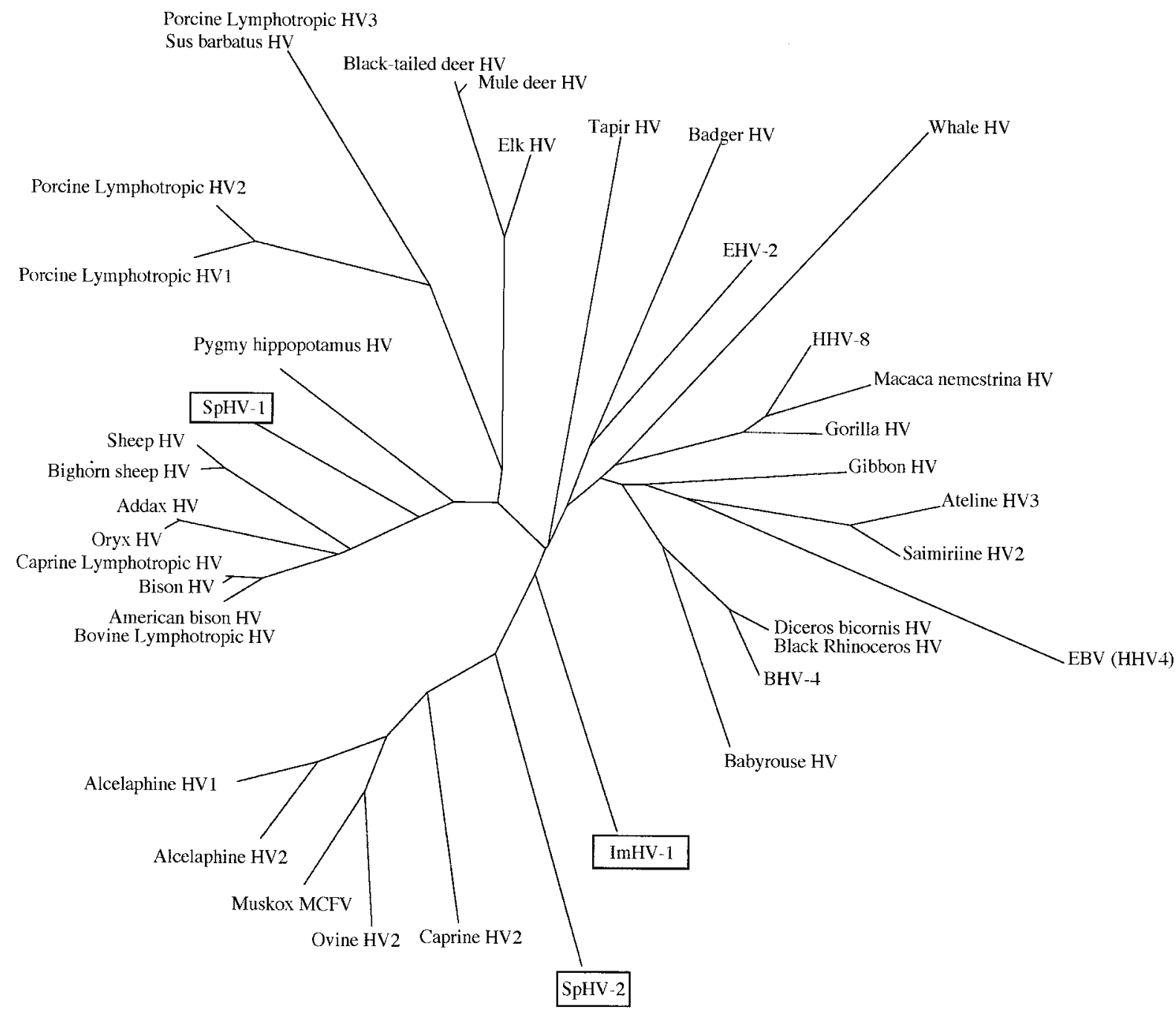

Fig.3. The phylogenetic tree based on the amino acid sequences of DNA polymerase gene in members of gammaherpesvirus. The phylogenetic tree was constructed using the amino acid sequences shown in Fig. 2.

Collins, J. K. 2003. J. Vet. Diagn. Invest. 15: 179-183.

11. Lange, B., Arbeter, A., Hewetson, J. and Henle, W. 1978. Int. J. Cancer. 22: 521-527.

12. Li, H., Dyer, N., Keller, J. and Crawford, T. B. 2000. J. Clin. Microbiol. 38: 1313-1318.

13. Li, H., Gailbreath, K., Bender, L. C., West, K., Keller, J. and Crawford, T. B. 2003. J. Wildl. Dis. 39: 875-880.

14. Ludweg, H. 1983. pp. 135-214. In: The Herpesviruses, vol 2 (Roizman, B.ed), Plenum, New York.

15. McGeoch, D. J., Cook, S., Dolan, A., Jamieson, F. E. and Telford, E. A. 1995. J. Mol. Biol. 247: 443-458.

16. Quackenbush, S, L., Work, T. M., Balazs, G. H., Casey, R. N., Rovnak, J., Chaves, A., duToit, L., Baines, J, D., Parrish, C. R., Bowser, P. R. and Casey, J. W. 1998. Virology 246: 392-399.

17. Reid, H. W. and Buxton, D. 1989. pp. 116-162. In: Herpesvirus Diseases of Cattle, Horses and Pigs (Wottmann, G, ed), Kluwer, Boston.

18. Richman, L. K., Montali, R. J., Garber, R. L., Kennedy, M. A., Lehnhardt, J., Hildebrandt, T., Schmitt, D., Hardy, D., Alcen- dor, D. J. and Hayward, G. S. 1999. Science 283: 1171-1176.

19. Rodda, S., Jack, I. and White, D.O. 1973. Lancet. 1: 13951396.

20. Roizman, B., Desrosies, R.C., Fleckenstein, B., Lopez, C., Minson, A. C. and Studdert, M. 1995. pp. 114-127. In: Virus Taxonomy (Murphy, F. A., Fauquet, C. M., Bishop, D. H. L., Ghabrial, S. A., Jarvis. A. W., Martelli, G. P., Mayo, M. A. and Summer, M. D. eds). 6th Report of the International Committee on Taxonomy of Viruses. Vienna and New York.

21. Rovnak, J., Quackenbush, S. L., Reyes, R. A., Baines, J. D., Parrish, C. R. and Casey, J. W. 1998. J. Virol. 72: 4237-4242.

22. Springfeld, C., Tidona, C. A., Kehm, R., Bahr, U. and Darai, G. 1998. J. Gen. Virol. 79: 3049-3053.

23. VanDevanter, D. R., Warrener, P., Bennett, L., Schultz, E. R., Coulter, S., Garber, R. L. and Rose, T. M. 1996. J. Clin. Microbiol. 34: 1666-1671.

24. Worthington, R. W. and Bigalke, R. D. 2001. J. Vet. Res. 68 291-323. 